\title{
KARAKTERISASI DAN APLIKASI PENANDA MIKROSATELIT PADA BEBERAPA Species Eucalyptus
}

Characterization and Application of Microsatellite Markers on Eucalyptus

\author{
ILG. Nurtjahjaningsih, AYPBC. Widyatmoko, dan A. Rimbawanto \\ Balai Besar Penelitian Bioteknologi dan Pemuliaan Tanaman Hutan \\ J1. Palagan Tentara Pelajar Km. 15, Purwobinangun, Pakem, Sleman, Yogyakarta 55582 \\ Iluh_nc@yahoo.com
}

\begin{abstract}
Genetically pure species that used as genetic materials represent crucial factors for succeed of a tree improvement strategy. Using microsatellite markers, private allele and genetic variation could genetically distinguish a species. Aims in this study were to characterize microsatellite markers on Eucalyptus deglupta, E. urophylla and E. pellita, and to assess private allele and genetic variation on the tree Eucalyptus. Results showed that 8, 10 and 12 out of 13 the screened microsatellite markers were amplified and polymorphic on E. deglupta, E. urophylla and E. pellita respectively. Private alleles characterized each Eucalyptus. Number of detected allele ranged between 29 (E. deglupta) and 91 (E. pellita). Value of expected heterozygosity was lowest on E. deglupta $\left(H_{E}=0.308\right)$ and highest on $E$. pellita $\left(H_{E}=0.604\right)$. Coefficient inbreeding value was insignificant deviate from $H W E$ on E. deglupta and E. urophylla, but it was significant on E. pellita. Taxonomy relationship and geographic position in natural distribution each Eucalyptus was discussed. For further study, population genetic and mating system will be important information on the Eucalyptus.
\end{abstract} Keywords: E.deglupta, E.urophylla, E.pellita, private allele, expected heterozygosity, coefficient
inbreeding

\begin{abstract}
ABSTRAK
Kemurnian secara genetik suatu jenis yang digunakan sebagai materi genetik merupakan faktor penting dalam keberhasilan suatu strategi pemuliaan pohon. Menggunakan penanda mikrosatelit, allele privat dan variasi genetik dapat membedakan secara genetik suatu jenis. Tujuan penelitian ini adalah untuk mengkarakterisasi penanda mikrosatelit pada Eucalytus deglupta, E. urophylla dan E. pellita, dan untuk mengetahui allele privat dan variasi genetik pada tiga jenis Eucalyptus tersebut. Hasil penelitian menunjukkan bahwa 8, 10 dan 12 dari 13 penanda mikrosatelit yang diuji dapat teramplifikasi dan bersifat polimorfik masing-masing pada E. deglupta, E. urophylla dan E. pellita. Allele privat mencirikan masing-masing jenis Eucalyptus yang diuji. Jumlah allele yang terdeteksi berkisar antara 29 (E. deglupta) dan 91 (E. pellita). Nilai heterozygositas harapan paling rendah pada E. deglupta $\left(H_{\mathrm{E}}=0,308\right)$ dan paling tinggi pada $E$. pellita $\left(H_{\mathrm{E}}=0,604\right)$. Nilai koefisien inbreeding tidak nyata menyimpang dari hukum keseimbangan Hardy-Weinberg pada E. deglupta dan E. urophylla, akan tetapi nilainya nyata pada E. pellita. Dari hasil tersebut, penelitian ini mendiskusikan kedekatan secara taksonomi, posisi geografis dan karakter penyebaran di sebaran alam masing-masing Eucalyptus. Untuk studi lebih lanjut, genetik populasi dan sistem perkawinan merupakan informasi penting pada masing-masing Eucalyptus.
\end{abstract}

Kata kunci: E. deglupta, E. urophylla, E. pellita, allele privat, heterozygositas harapan, koefisien inbreeding

\section{PENDAHULUAN}

Sebaran alam jenis Eucalyptus sebagian besar ada di Australia, sebagian di Papua New Guinea dan hanya dua jenis yang tersebar di Indonesia Bagian Timur, yaitu E. deglupta Bl dan E. urophylla S.T. Blake (Eldridge dkk., 1997). E. deglupta tersebar secara terpisah-pisah, daerah sebarannya terletak di bagian Utara khatulistiwa yaitu Papua Barat, Seram dan Sulawesi; E. urophylla tersebar secara lebih luas di Pulau Wetar, Timor, Alor, Pantar, Lomblen, Adonara, dan Flores; 
sedangkan E. pellita F. Muell memiliki sebaran alam yang dipisahkan oleh area yang luas yaitu di Papua Barat (Indonesia), PNG dan Australia Bagian Utara (Eldridge dkk., 1997). Genus Eucalyptus termasuk dalam famili Myrtaceae, mempunyai delapan subgenus diantaranya Symphyomyrtus dan Telocalyptus. Eucalyptus urophylla, dan E. pellita, termasuk dalam subgenus yang sama yaitu Symphyomyrtus, sedangkan E. deglupta. berbeda subgenus yaitu Telocalyptus (Eldridge dkk., 1997). Polinasi pada Eucalyptus dibantu oleh serangga, mudah untuk berkawin sendiri (selfpollination), sehingga cenderung mengalami depresi inbreeding (Chaix dkk., 2003). Selain itu, beberapa Eucalyptus juga mudah untuk melakukan hibridisasi antar jenis.

Di Indonesia, Eucalyptus deglupta, E. urophylla dan E. pellita merupakan jenisjenis prioritas HTI untuk tujuan pembuatan bahan baku kertas dan kertas. Hutan tanaman maupun strategi pemuliaan pada jenis-jenis tersebut sudah ditetapkan sejak tahun 1980an dalam rangka meningkatkan produktifitas. Proses hibridisasi antar jenis sering terjadi secara alam apabila jenis tertentu berada pada habitat yang sama atau mempunyai kecocokan secara genetik karena berkerabat dekat (Dering dan Chybicki, 2012). Hibridisasi alam juga terjadi antar jenisjenis dalam genus Eucalyptus (Eldridge dkk., 1997; McKinnon dkk., 1999). Analisis menggunakan penanda DNA mampu menunjukkan allele spesifik sehingga mampu membedakan suatu jenis tertentu dari jenis yang lain. Nilai keragaman genetik merupakan faktor penting untuk mendukung keberhasilan suatu strategi pemuliaan (Avramidou dkk., 2010). Nilai keragaman genetik yang rendah tidak mendukung untuk dilakukannya seleksi pohon secara intensif dalam suatu strategi pemuliaan. Selain itu, keragaman genetik yang rendah pada sebuah populasi pemuliaan harus diperlebar dengan cara memasukan infusi genetik dari populasi alam. Oleh karena itu, identifikasi keragaman genetik pada suatu jenis perlu dilakukan (Avramidou dkk., 2010). Untuk menjamin ketersediaan benih unggul sehingga meningkatkan keberhasilan produksi hutan tanaman dan strategi pemuliaan selanjutnya, informasi kemurnian suatu jenis dan potensi genetik menggunakan penanda DNA merupakan salah satu aspek penting dalam manajemen kebun benih.

Mikrosatelit atau simple sequence repeat (SSR) merupakan salah satu penanda DNA yang mempunyai sekuen sederhana, terdiri dari satu sampai enam basa yang diulang, dan banyak dijumpai pada genom tanaman (Brondani dkk., 1998). Tingkat polimorfisme yang tinggi menyebabkan penanda mikrosatelit mampu membedakan jenis dan individu yang berkerabat secara genetik (Burke dan Long, 2012). Metode screening primer mikrosatelit dari jenis lain adalah salah satu metode untuk menyediakan 
penanda mikrosatelit; metode ini dipandang lebih menghemat waktu, tenaga dan biaya dibandingkan dengan metode penyusunan pustaka DNA (Jan dkk., 2012; McCulloch dan Stevens, 2011). Adanya kemiripan susunan basa pada jenis yang berkerabat mendasari dikembangkannya metode ini. Keberhasilan metode screening primer mikrosatelit cukup tinggi, terutama pada jenis-jenis dalam satu genus atau subgenus (Ujino dkk., 1998). Penanda mikrosatelit sudah dikembangkan pada E. grandis dan E. urophylla (Brondani dkk., 1998). Pada penelitian akan mengaplikasikan penanda yang telah dikembangkan tersebut pada $E$. deglupta, E. urophylla dan E. pellita.

Tujuan penelitian ini adalah untuk mengkarakterisasi penanda mikrosatelit pada Eucalytus deglupta, E. urophylla dan E. pellita, dan untuk mengetahui allele privat dan variasi genetik pada tiga jenis Eucalyptus tersebut.

\section{BAHAN DAN METODE} Pengambilan sampel dan ekstraksi DNA

Contoh/sampel daun E.deglupta dan E. urophylla untuk analisis DNA, diambil dari arboretum Balai Besar Penelitian Bioteknologi dan Pemuliaan Tanaman Hutan, Yogyakarta, sedangkan E. pellita diambil dari kebun benih semai uji keturunan (KBSUK), terletak di Pleihari, Kalimantan Selatan; masing-masing Eucalyptus tersebut dikumpulkan dari sebaran alamnya. Jumlah sampel masing-masing jenis sebanyak 8,6 dan 16 daun. Masing-masing sampel daun dimasukkan ke dalam kantong plastik dan disimpan dalam deep freezer $\left(-20^{\circ} \mathrm{C}\right)$ sampai dilakukan ekstraksi DNA.

Sampel daun segar dari masing- masing jenis tersebut ditimbang seberat $100 \mathrm{mg}$ dan dihaluskan menggunakan mesin mini bead seri M-301 (Retsch). Ekstraksi DNA menggunakan metode modifikasi CTAB (Shiraishi dan Watanabe, 1995).

\section{Analisis penanda SSR}

Reaksi PCR untuk metode screening penanda mikrosatelit terdiri atas $10 \mu \mathrm{L}$ larutan yang terdiri dari 1 x PCR buffer (Applied Biosystem), 25mM $\mathrm{MgCl}_{2}, 2,5$ $\mu \mathrm{M}$ dNTP, multiplex primer masing-masing 0,5 $\mu \mathrm{M}$, AmpliTaq Gold DNA polymerase (Applied Biosystem) dan 5 ng template DNA. Penelitian ini menggunakan 13 penanda mikrosatelit yang sudah dikembangkan dari E. grandis dan E. urophylla. Sekuen pasangan primer dan karakterisasi penanda ini sudah diuraikan oleh Brondani dkk. (1998).

Proses PCR dilakukan menggunakan thermocycler GeneAmp9700 (Applied Biosystem). Suhu pemanasan awal $94^{\circ} \mathrm{C}$ selama 10 menit, diikuti dengan 10 siklus reaksi yang masing-masing terdiri dari reaksi denaturasi DNA (suhu $94^{\circ} \mathrm{C}$ selama 30 detik), reaksi penempelan primer (annealing) mengikuti protokol touchdown pada suhu $65^{\circ}-55^{\circ} \mathrm{C}$ selama 30 detik dan pemanjangan DNA pada suhu $72^{\circ} \mathrm{C}$ selama 60 detik. 
Kemudian diikuti 25 siklus reaksi yang terdiri dari reaksi denaturasi dan pemanjangan DNA seperti yang disebutkan di atas dan reaksi penempelan primer pada suhu $55^{\circ} \mathrm{C}$ selama 30 detik. Siklus PCR diakhiri pada suhu $72^{\circ} \mathrm{C}$ selama 1 menit untuk melengkapi proses pemanjangan. Elektroforesis hasil PCR menggunakan mesin gene analyzer ABI 3100 Avant (Applied Biosystem). Fragment DNA dianalisis menggunakan software genemapper.

\section{Analisis Data}

Parameter yang digunakan untuk mengkarakterisasi penanda mikrosatelit adalah allele privat dan keragaman genetik per lokus per jenis. Allele privat adalah allele yang muncul hanya pada satu jenis saja. Parameter yang digunakan untuk mengetahui keragaman genetik per lokus per jenis adalah jumlah allele yang terdeteksi $\left(N_{\mathrm{A}}\right)$, heterozygositas observasi $\left(H_{\mathrm{O}}\right)$, heterozygositas harapan $\left(H_{\mathrm{E}}\right)$ dan koefisien inbreeding $\left(F_{\text {IS }}\right)$. Allele privat dan parameter keragaman genetik per lokus per jenis dianalisis menggunakan program komputer $F_{\text {STAT }}($ Goudet, 2001).
Analisis principal coordinat (PCA) dihitung untuk melihat kedekatan genetik antar Eucalyptus yang dihubungkan dengan letak geografis masing-masing jenis. Analisis PCA dihitung menggunakan program komputer GENALEX versi 6.4 (Peakall dan Smouse, 2006). Sebuah dendrogram disusun dari data frekuensi allele untuk menggambarkan kedekatan genetik antar jenis Eucalyptus dan dianalisis menggunakan program komputer POPTREE (Takezaki dkk., 2010).

\section{HASIL DAN PEMBAHASAN}

\section{A. Hasil}

\subsubsection{Allele privat pada tiga jenis Eucalyptus}

Jumlah allele privat pada E. deglupta, E. urophylla dan E. pellita ditunjukkan pada Tabel 1. Allele privat adalah allele yang dimiliki hanya pada satu jenis Eucalyptus saja sehingga menunjukkan karakter masing-masing jenis tersebut. Jenis $E$. pellita memiliki allele privat paling banyak (60 allele) diantara E. deglupta (9 allele) dan E. urophylla (29 allele).

Tabel 1. Allele privat pada masing-masing Eucalyptus menggunakan 13 penanda mikrosatelit

\begin{tabular}{|l|l|l|l|}
\hline \multirow{2}{*}{ Nama lokus } & \multicolumn{3}{|c|}{ Ukuran allele privat (bp) } \\
\cline { 2 - 4 } & \multicolumn{1}{|c|}{ E. deglupta } & \multicolumn{1}{c|}{ E. urophylla E. pellita } \\
\hline $\mathrm{N}$ & 8 & 6 & 16 \\
\hline EMBRA5 & 0 & 117,137 & $95,111,115,126$ \\
\hline EMBRA6 & 0 & 0 & $95,112,116,118,126,128$ \\
\hline EMBRA7 & 134,137 & $148,169,171$ & $139,150,152,156,158,164$ \\
\hline EMBRA8 & 137 & 0 & $129,141,143,149,159,163$ \\
\hline EMBRA9 & 137 & 0 & $112,116,123,125,129,133,141,143,149$ \\
\hline EMBRA10 & 151 & $114,124,130$ & 140,144 \\
\hline EMBRA11 & 140 & $123,130,132,136$ & 0 \\
\hline EMBRA12 & 138 & 122,126 & $109,113,119,130,132,154$ \\
\hline EMBRA13 & 0 & 0 & 69 \\
\hline EMBRA15 & 126 & $116,122,124,128$ & $86,88,91,95,109$ \\
\hline EMBRA16 & 0 & $130,136,138,144,148,152$ & $106,108,124$ \\
\hline EMBRA17 & 0 & $136,146,170,172$ & $127,130,133,142,144,162,164,176$ \\
\hline EMBRA20 & 138 & 117 & $130,146,148,150$ \\
\hline Jumlah & 9 & 29 & 60 \\
\hline
\end{tabular}




\subsubsection{Karakterisasi penanda mikrosatelit dan keragaman genetik per lokus pada tiga jenis Eucalyptus}

Amplifikasi penanda mikrosatelit pada E. deglupta, E. urophylla dan E. pellita dapat diklasifikasikan sebagai primer yang tidak menghasilkan ukuran allele (primer tidak teramplifikasi), primer teramplifikasi hanya menghasilkan 1 allele (primer monomorfik) dan primer teramplifikasi dengan banyak allele (primer polymorfik) (Tabel 2). Dari 13 primer tersebut, amplifikasi penanda mikrosatelit pada E. deglupta menghasilkan 1 primer tidak teramplifikasi, 4 primer monomorfik dan 8 primer polymorfik. Semua penanda mikrosatelit teramplifikasi pada E. urophylla, 3 primer bersifat monomorfik dan 10 primer polymorfik. Sedangkan amplifikasi penanda mikrosatelit pada E. pellita menghasilkan 1 primer tidak teramplifikasi dan 12 primer polymorfik. Dari jumlah primer yang teramplifikasi, baik yang bersifat monomorfik maupun polimorfik, keberhasilan screening primer mikrosatelit pada E. deglupta, E. urophylla dan E. pellita masing-masing sebesar 92,3\%, $100 \%$ dan $92,3 \%$.

Dengan hanya menyertakan primer monomorfik dan polimorfik, parameter keragaman genetik per lokus pada masingmasing jenis Eucalyptus ditunjukkan pada Tabel 2. Jumlah allele yang terdeteksi per lokus pada E. deglupta mempunyai nilai kisaran paling rendah $\left(\mathrm{N}_{\mathrm{a}}: 1-5\right.$ alelle $)$ apabila dibandingkan dengan E. urophylla $\left(\mathrm{N}_{\mathrm{a}}: 1-7\right.$ allele) dan E. pellita $\left(\mathrm{N}_{\mathrm{a}}: 3-13\right.$ allele). Nilai $H_{\mathrm{O}}$ per lokus mempunyai kisaran yang sama pada E.deglupta dan E. pellita $\left(H_{\mathrm{O}}: 0,125-\right.$ 0,875), dengan nilai $H_{\mathrm{O}}$ rata-rata masingmasing 0,231 dan 0,533 , sedangkan nilainya lebih tinggi pada E.urophylla $\left(H_{\mathrm{O}}: 0,500\right.$ 1,000) dengan nilai $H_{\mathrm{O}}$ rata-rata sebesar 0,585. Nilai $H_{\mathrm{E}}$ per lokus pada E. deglupta relatif rendah $\left(H_{\mathrm{E}}=0,117-0,765 ; H_{\mathrm{E}}\right.$ ratarata $=0,308)$ dibandingkan nilai $H_{\mathrm{E}}$ pada E. urophylla $\left(H_{\mathrm{E}}: 0,514-0,819 ; H_{\mathrm{E}}\right.$ rata-rata $=0,531)$ dan E. pellita $\left(H_{\mathrm{E}}: 0,145-0,887\right.$; $H_{\mathrm{E}}$ rata-rata $\left.=0,604\right)$. Empat dari 8 primer polimorfik pada E. deglupta mempunyai nilai $F_{\text {IS }}$ tinggi dan secara nyata meyimpang dari hukum keseimbangan Hardy-Weinberg (HW). Hal yang sama juga ditunjukkan pada 4 dari 12 primer pada $E$. pellita. Total nilai $F_{\text {IS }}$ pada E. deglupta dan E. urophylla tidak nyata menyimpang dari hukum keseimbangan HW, akan tetapi nilainya nyata menyimpang pada E. pellita. 


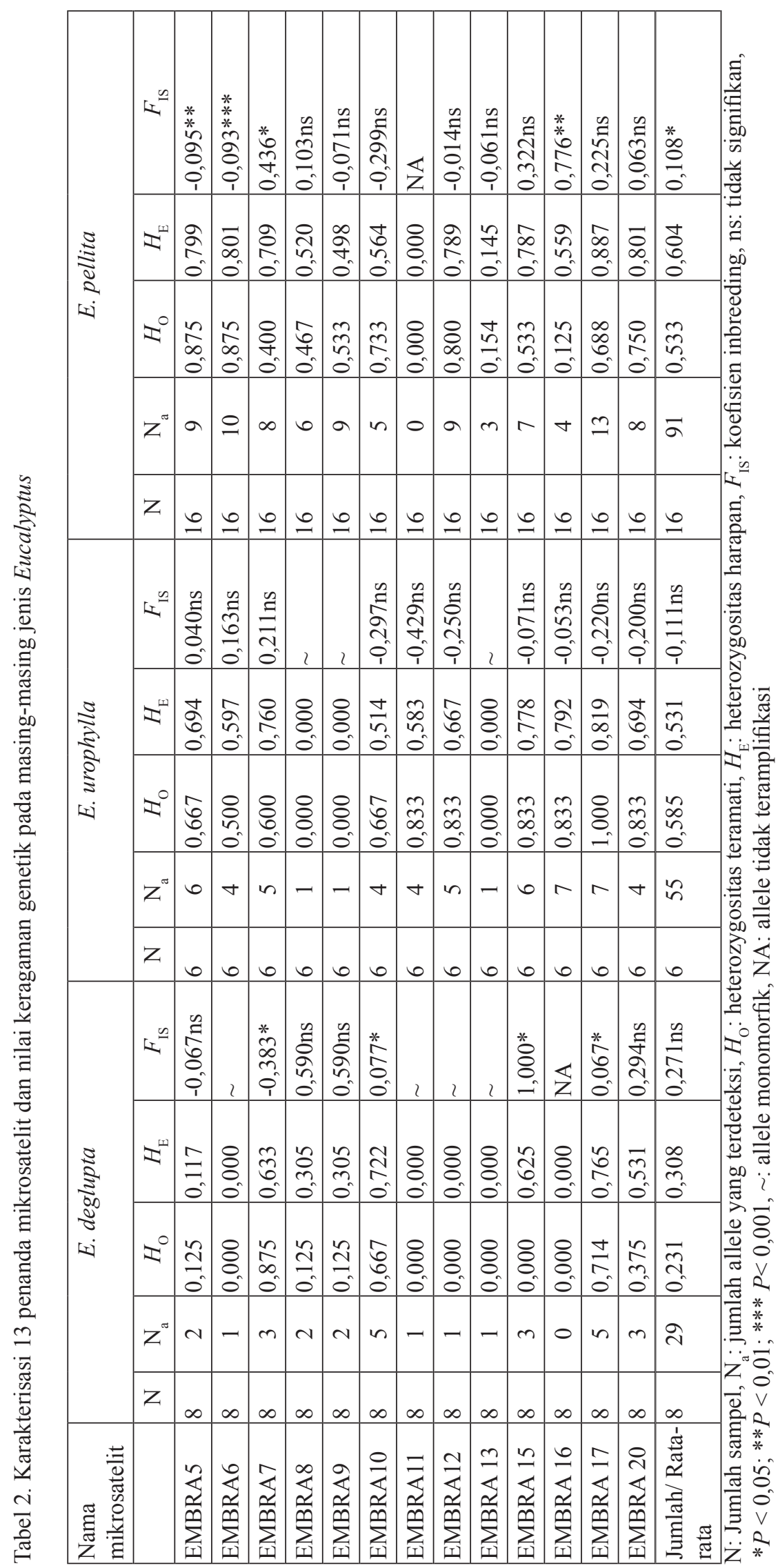




\subsubsection{Keragaman genetik antar jenis Eucalyptus}

Analisis PCA dalam dua dimensi ruang (ordinat $\mathrm{xy}$ ), menunjukkan nilai total varian yang tinggi pada koordinat pertama (46\%; Gambar 1). Individu pohon dengan identitas u1 sampai dengan u6 mengelompok dalam jenis E. urophylla; d1 sampai dengan d8 mengelompok dalam jenis $E$. deglupta sedangkan p1 sampai dengan p16 mengelopmok dalam jenis E. pellita, kecuali p12. Kelompok-kelompok ini menunjukkan bahwa masing-masing jenis Eucalyptus tersebut berbeda satu dengan yang lain. Apabila dilihat pada koordinat 1, individu E. urophylla dan E. deglupta mengelompok pada sisi ordinat yang sama (sebelah kanan dari ordinat $Y$ ), sedangkan E. pellita terdapat pada sisi ordinat yang lain (sebelah kiri ordinat Y). Analisis PCA mengidentifikasi tiga kelompok secara jelas; masing-masing genotipe mengelompok berdasarkan jenis dan asal geografis masing-masing jenis.

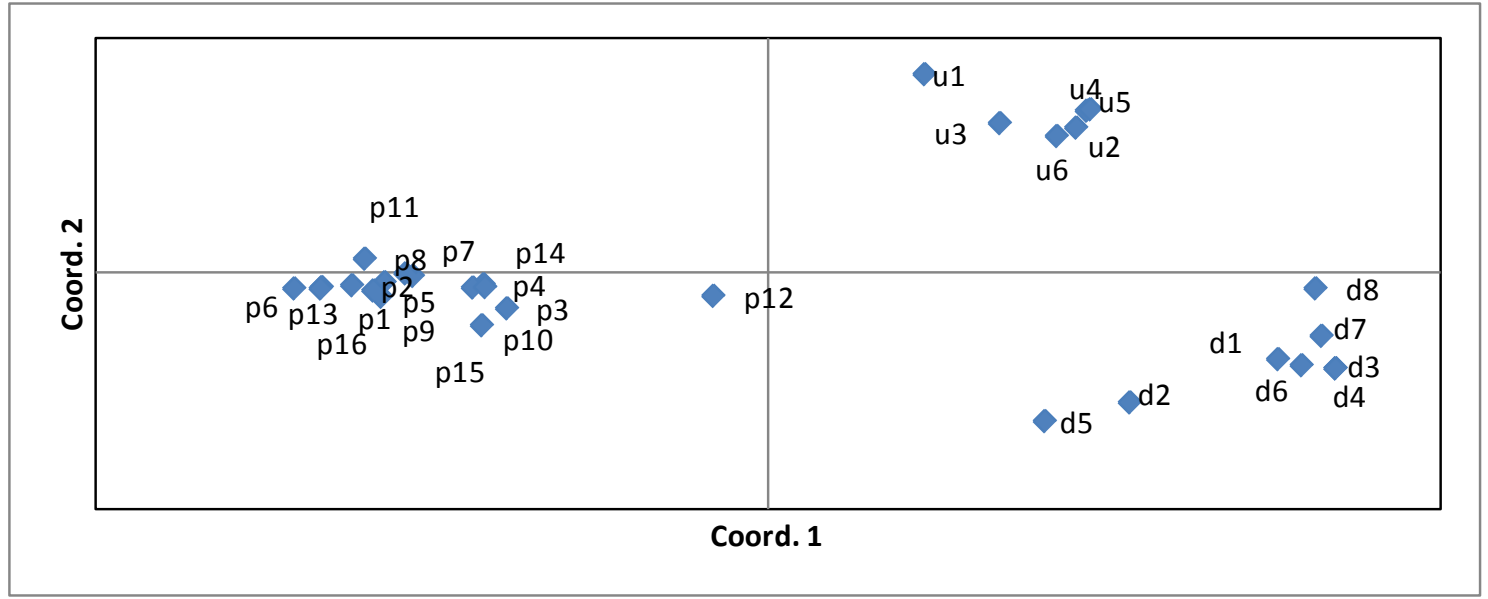

Gambar 1. Analisis prinsip kordinat antar individu pada tiga jenis Eucalyptus

Keterangan: d1-d8: individu E. deglupta no. 1 s/d 8, u1-u6: individu E. urophylla no. 1 s/d 6, p1-p16: individu E. pellita no. $1 \mathrm{~s} / \mathrm{d} 16$

Analisis klaster menunjukkan klaster dengan E. urophylla, sedangkan E. kedekatan secara genetik antar jenis E. pellita membentuk kelompok yang lain. deglupta, E. urophylla dan E. pellita Meskipun E. deglupta dan E. urophylla (Gambar 2). Analisis ini mendukung hasil mengelompok dalam satu kluster, namun yang diperoleh pada analisis PCA. Jenis $E$. deglupta mengelompok menjadi satu sub dua jenis ini terpisah secara jelas dengan tingkat kepercayaan 100\%. 


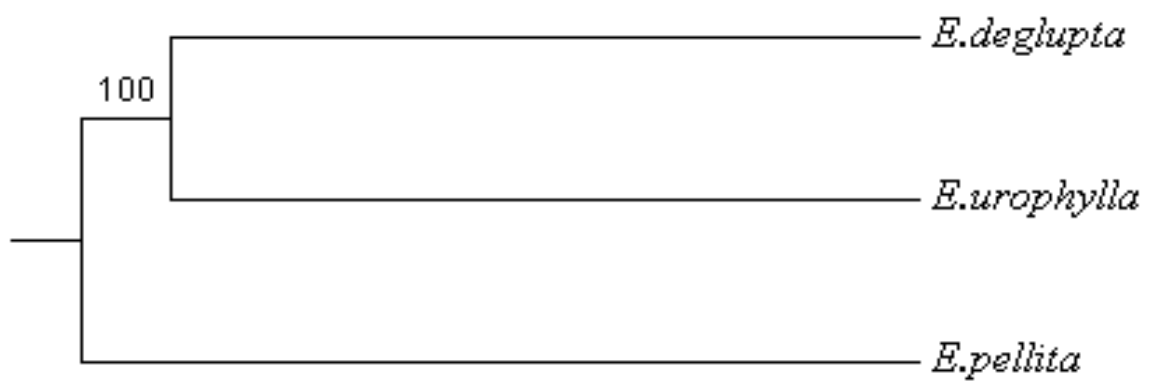

\section{$\longmapsto .1$}

\subsection{Pembahasan}

Keberhasilan metode screening mikrosatelit pada penelitian ini cukup tinggi $(>90 \%)$ apabila dibandingkan screening pada jenis Pinus (Mariette dkk., 2001) maupun jenis daun lebar lainnya (Ujino dkk., 1998). Salah satu faktor yang menentukan keberhasilan metode screening primer adalah kedekatan genetik masing-masing jenis secara taksonomi atau jarak filogenetik (Brondani dkk., 1998; Chandra dkk., 2011). Keberhasilan metode screening bisa lintas subgenus, genus, sub-famili, bahkan famili (McCulloch dan Stevens, 2011; Nagy dkk., 2007; Poncet dkk., 2007). Penanda mikrosatelityang digunakan dalam penelitian ini dapat teramplifikasi dengan baik pada $E$. grandis dan E. urophylla, yang dalam hal ini kedua species tersebut termasuk dalam satu subgenus yang sama yaitu Symphyomyrtus (Brondani dkk., 1998). Penelitian ini juga menunjukkan bahwa keberhasilan amplifikasi penanda mikrosatelit Eucalyptus pada E. pellita dan E. urohpylla lebih tinggi apabila dibandingkan dengan $E$. deglupta. Hal ini disebabkan karena $E$. pellita dan E. urophylla termasuk dalam subgenus yang sama yaitu Symphyomyrtus, sedangkan $E$. deglupta berbeda subgenus yaitu Telocalyptus (Eldridge dkk., 1997). Metode screening penanda pada jenis Shorea, menunjukkan keberhasilan yang tinggi apabila dilakukan pada genus Shorea. Namun demikian, keberhasilan metode screening menurun apabila dilakukan terhadap jenis lain, meskipun dalam taksa yang sama yaitu Dipterocarpaceae (Ujino dkk., 1998). Meskipun screening primer berasal dari E. urophylla, tidak semua primer mengamplifikasikan allele polimorfik pada E. urophylla yang digunakan pada penelitian ini. Hal yang sama juga dilaporkan pada Pinus pinaster, bahwa metode screening tidak selalu berhasil meskipun pada species yang sama (Mariette dkk., 2001). Hal ini menunjukkan bahwa selain kedekatan secara taksonomi, ukuran dan kompleksitas susunan DNA juga merupakan faktor 
penting dalam keberhasilan metode screening. Keberhasilan metode screening akan lebih rendah apabila diterapkan pada species yang mempunyai ukuran DNA yang besar dan kompleks seperti pada genom Pinus (Kinlaw dan Neale, 1997). Kesulitan penggunaan metode screening untuk mengaplikasikan penanda mikrosatelit pada Pinus telah banyak dilaporkan (Echt dkk., 1999; Mariette dkk., 2001). Besarnya penyimpangan genetik yang disebabkan oleh proses evolusi juga berpengaruh terhadap keberhasilan amplifikasi mikrosatelit, bahkan penyimpangan tersebut bervariasi antar lokus (Jan dkk., 2012). Selain itu, allele polimorfik dipengaruhi oleh sempurna atau tidaknya struktur ulangan mikrosatelit (Jan dkk., 2012). Laju mutasi akan menginterupsi susunan basa pada sekuen mikrosatelit sehingga struktur ulangan tidak sempurna, hal ini mempengaruhi tingkat polimorfisme amplifikasi allele, atau bahkan tidak teramplifikasi. Selain itu, menurunnya jarak filogenetik antar jenis pun mempengaruhi polimorfisme allele (Jan dkk., 2012).

Amplifikasi allele 13 primer yang digunakan dalam penelitian ini menunjukkan ukuran dan susunan allele yang berbedabeda pada ketiga Eucalyptus tersebut. Adanya allele privat untuk jenis tertentu menunjukkan karakter spesifik pada tiap jenis tersebut (McCulloch dan Stevens, 2011), sehingga penanda mikrosatelit dapat digunakan untuk membedakan jenis (Jan dkk., 2012). Selain itu, Ujino dkk. (1998) melaporkan bahwa ukuran fragmen DNA yang sama tidak selalu menunjukkan kesamaan dalam sekuen DNA, sehingga amplifikasi ukuran allele akan berbeda-beda pada masing- masing individu.

Hasil parameter keragaman genetik menunjukkan bahwa E. deglupta mempunyai variasi genetik yang paling rendah diantara E. urophylla dan E. pellita. Nilai keragaman genetik yang lebih rendah pada E. deglupta bisa disebabkan oleh pola sebaran populasi di hutan alam yang bersifat tidak menyambung, berbeda dengan sebaran alam E. urophylla dan E. pellita yang lebih luas dan menyambung (Eldridge dkk., 1997). Sebaran yang tidak menyambung (terfragmentasi) menghambat proses gene flow atau laju migrasi per generasi sehingga berpengaruh pada struktur gen dan menyebabkan rendahnya nilai keragaman genetik (Hu dkk., 2010; Karan dkk., 2012). Namun demikian, meskipun nilai keragaman genetik pada E. deglupta lebih rendah, akan tetapi nilai koefisien inbreeding jenis ini tidak menunjukkan defisit heterozigositas diban- dingkan E. pellita. Hal ini menunjukkan bahwa individu E. deglupta yang digunakan pada penelitian berasal dari sistem perkawinan yang acak (random) dengan ukuran populasi yang luas. Sebaliknya, meskipun nilai keragaman genetik pada $E$. pellita lebih tinggi namun nilai koefisien inbreeding menunjukkan defisit heterozi- 
gositas secara nyata. Defisit heterozigositas disebabkan oleh adanya null allele, yaitu amplifikasi allele semu saat proses PCR atau mutasi genetik di populasi alam (Moriguchi dkk., 2003). Null allele sangat mengganggu proses analisis genetik karena menyebabkan kesalahan membaca allele, sehingga penanda/primer yang mengandung null allele tidak digunakan dalam analisis genetik. Namun demikian, penelitian ini belum bisa membuktikan adanya null allele karena jumlah sampel yang tidak terlalu banyak $(\mathrm{N}=16)$. Pembuktian adanya null allele bisa dilakukan dengan menambah jumlah populasi maupun jumlah sampel. Idealnya, semakin banyak populasi yang digunakan dan beragam, maka semakin mudah untuk membuktikan keberadaan null allele. Selain itu, penggunaan sampel individu yang berkerabat secara genetik juga menyebabkan tingginya koefisien inbreeding dan nilainya signifikan.

Analisis PCA menunjukkan bahwa individu-individu Eucalyptus mengelompok berdasarkan jenisnya. Hal ini menunjukkan bahwa kemurnian genetik masing-masing Eucalyptus masih terjaga. Analisis PCA diaplikasikan pada Prunus avium untuk membedakan suatu varietas dengan jenis liar (Avramidou dkk., 2010). Varietas P. avium mengelompok namun berdekatan dengan asal dari jenis liarnya. Analisis PCA sering menunjukkan lokasi geografis dengan analisis genetik suatu jenis (Ghamkhar dkk.,
2010; Manel dkk., 2010; Tsuda dan Ide, 2005). Penelitian ini mendukung pendapat tersebut, bahwa secara geografis, sebaran alam E. deglupta lebih dekat dengan $E$. urophylla dibandingkan E. pellita. Secara geografis, wilayah sebaran E. deglupta lebih dekat dengan wilayah E. urophylla.

Analisis klaster juga menunjukkan bahwa hubungan kekerabatan secara genetik antara E. deglupta dan E. urophylla mempunyai hubungan yang lebih dekat apabila dibandingkan dengan E. pellita. Apabila dilihat dari sisi taksonomi antara tiga Eucalyptus tersebut, E. deglupta berbeda subgenus dengan E. urophylla dan E. pellita. Namun demikian menggunakan analisis kluster E. deglupta berada dalam satu kluster dengan E. urophylla. Sebaliknya, posisi geografis sebaran alam E. deglupta dan E. urophylla lebih dekat dibandingkan E. pellita. Hal ini menunjukkan bahwa adaptasi terhadap lingkungan yang sama (dalam hal ini lingkungan tropis) menyebabkan persamaan dalam struktur gen. Hal yang sama juga dilaporkan oleh Hu dkk. (2010) bahwa proses evolusi dan adaptasi menyebabkan perbedaan struktur gen. Studi lain melaporkan bahwa Eucalyptus subgenus monocalyptus mengindikasikan hubungan kedekatan posisi geografis lebih sesuai dibandingkan hubungan taksonomi yang didasarkan pada morfologi (McKinnon dkk., 1999). 


\section{KESIMPULAN}

Keberhasilan metode screening penanda pada E. deglupta, E. urophylla dan E. pellita cukup tinggi (>90\%). Perbedaan keberhasilan metode screening pada tiga Eucalyptus tersebut dapat disebabkan oleh perbedaan jarak genetik dalam taksonomi antar jenis. Sejumlah 9, 29 dan 60 allele privat mencirikan masingmasing E. deglupta, E. urophylla dan E. pellita. Rendahnya nilai keragaman genetik pada E. deglupta dibandingkan dengan E. urophylla dan E. pellita disebabkan karena penanda mikrosatelit tidak cukup terkonservasi pada subgenus yang berbeda atau dapat disebabkan oleh karakter sebaran alam populasi E. deglupta yang terpisahpisah. Meskipun demikian, nilai koefiesien inbreeding pada jenis ini tidak nyata defisit heterozigositas yang menunjukkan bahwa jenis tersebut berasal dari sistem perkawinan random. Analisis PCA menunjukkan pengelompokan individu pada setiap jenis, hal ini mengindikasikan kemurnian genetik masing-masing Eucalyptus masih terjaga. Analisis klaster menunjukkan bahwa meskipun tidak dalam sub genus yang sama, E. deglupta dan E. urophylla mempunyai hubungan genetik yang lebih dekat dibandingkan dengan E. pellita.

\section{DAFTAR PUSTAKA}

Avramidou, E., Ganopoulos, I. V., and Aravanopoulos, F. A. (2010). DNA fingerprinting of elite Greek wild cherry
(Prunus avium L.) genotypes using microsatellite markers. Forestry, 83(5).

Brondani, R. P. V., Brondani, C., Tarchini, R., and Grattapaglia, D. (1998). Development, characterization and mapping of microsatellite markers in Eucalyptus grandis and E. urophylla. Theor Appl Genet, 97: 816-827.

Burke, M.K., and Long,A.D. (2012). Perspective: What paths do advantageous alleles take during short-term evolutionary change? Molecular Ecology, 21: 4913-4916.

Chaix, G., Gerber, S., Razafimaharo, V., Vigneron, P., Verhaegen, D., and Hamon, S. (2003). Gene flow estimation with microsatellites in a Malagasi seed orchard of Eucalyptus grandis. Theor Appl Genet, 107: 705-712.

Chandra, A., Tiwari, K. K., Nagaich, D., Dubey, N., Kumar, S., and Roy, A. K. (2011). Development and characterization of microsatellite markers from tropical forage Stylosanthes species and anlysis of genetic variability and cross-species transferability. Genome, 54: 1016-1028.

Dering, M., and Chybicki, I. (2012). Assessment of genetic diversity in two-species oak seed stands and their progeny populations. Scandinavian Journal of Forest Research, 27: 2-9.

Echt, C. S., Vendramin, G. G., Nelson, C. D., and Marquardt, P. (1999). Microsatellite DNA as shared genetic markers among conifer species. Can. J. For. Res, 29: 365-371.

Eldridge, K., Davidson, J., Harwood, C., and Wyk, G. v. (1997). Eucalyptus domestication and breeding: Oxford Science Publications pp. 288.

Ghamkhar, K., Croser, J., Aryamanesh, N., Campbell, M., Kon'kova, N., and Francis, C. (2010). Camelina (Camelina sativa (L.) Crantz) as an alternative oilseed: molecular and ecogeographic analyses. Genome, 53: 558-567.

Goudet, J. (2001). FSTAT (version 2.9.3): A program to estimate and test gene diversities and fixatin indices. Retrieved from www.unil.ch/izea/softwares/fsat. html website:

Hu, L.-J., Uchiyama, K., Saito, Y., and Ide, Y. (2010). Contrasting patterns of nuclear microsatellite genetic structure of 
Fraxinus mandshurica var. japonica between northern and southern populations in Japan. Journal of Biogeography (J. Biogeogr), 37: 11311143.

Jan, C., Dawson, D. A., Altringham, J. D., Burke, T., and Butlin, R.K. (2012). Development of conserved microsatellite markers of high cross-species utility in bat species (Vespertilionidae, Chiroptera, Mammalia). Molecular Ecology Resources, 12: 532-548.

Karan, M., Evans, D. S., Reilly, D., Schulte, K., Wright, C., Innes, D., Holton, T. A., Nikles, D. G., and Dickinson, G. R. (2012). Rapid microsatellite marker development for African mahogany (Khaya senegalensis, Meliaceae) using next-generation sequencing and assessment of its intra-specific genetic diversity. Molecular Ecology Resources, 12: 344-353.

Kinlaw, C. S., and Neale, D. B. (1997). Complex gene families in pine genomes. Trends in plant science, 2(9): 356-359.

Manel, S., Poncet, B. N., Legendre, P., Gugerlis, F., and Holdereggers, R. (2010). Common factors drive adaptive genetic variation at different spatial scales in Arabis alpina. Molecular Ecology, 19: 3824-3835.

Mariette, S., Chagne, D., Decroocq, S., Vendramin, G. G., Lalanne, C., Madur, D., and Plomion, C. (2001). Microsatellite markers for Pinus pinaster Ait. Ann. For. Sci, 58: 203-206.

McCulloch, E. S., and Stevens, R. D. (2011). Rapid development and screening of microsatellite loci for Artibeus lituratus and their utility for six related species within Phyllostomidae. Molecular Ecology Resources, 11: 903-913.

McKinnon, G. E., Steane, D. A., Potts, B. M., and Vaillancourt, R. E. (1999). Incongruence between chloroplast and species phygenies in Eucalyptus Subgenus Monocalyptus (Myrtaceae). American Journal of Botany, 86(7): 1038-1046.

Moriguchi, Y., Iwata, H., Ujino-Ihara, T., Yoshimura, K., Taira, H., and Tsumura, Y. (2003). Development and characterization of microsatellite markers for Cryptomeria japonica D.Don. Theor Appl Genet, 106: 751758.

Nagy, I., Stagel, A., Savari, Z., Roder, M., and Ganal, M. (2007). Development, characterization, and transferability to other Solanaceae of microsatellite markers in pepper (Capsicum annum L.). Genome, 50: 668-688.

Peakall, R., and Smouse, P. E. (2006). GENALEX 6: genetic analysis in Excel, Population genetic software for teaching and research. Molecular Ecology Notes, 6: 288-295

Poncet, V., Dufour, M., Hamon, P., Hamon, S., Kochko, A. d., and Leroy, T. (2007). Development of genomic microsatellite markers in Coffea canephora and their transferability to other coffee species. Genome, 50: 1156-1161.

Shiraishi, S., and Watanabe, A. (1995). Identification of chloroplast genome between Pinus densiflora Sieb et Zucc and $P$. thumbergii Parl based on the polymorphism in $r b c \mathrm{~L}$ gene. Journal of Japanese Forestry Society, 77: 429-436.

Takezaki, N., Nei, M., and Tamura, K. (2010). Software for constructing population trees from allele frequency data and computing other population statistics with windows interface. Molecular Biology Evolution, 24(4): 747-752.

Tsuda, Y., and Ide, Y. (2005). Wide-range analysis of genetic structure of Betula maximowicziana, a long-lived pioneer tree species and noble hardwood in the cool temperate zone of Japan. Molecular Ecology, 14: 3929-3941.

Ujino, T., Kawahara, T., Tsumura, Y., Nagamitsu, T., Yoshimaru, H., and Ratnam, W. (1998). Development and polymorphism of simple sequnce repeat DNA markers for Shorea curtisii and other Dipterocarpaceae species. Heredity, 81: 422-428. 